\title{
Secondary Public School Teachers' Commitment to the Code of Ethical Conduct and Its Relationship with the Quality of Their Performance: Standpoints from Principals and Assistant Principals
}

\author{
Hanan Mohammad Obiedat \\ PhD candidate, Foundations of Education, School of Educational Sciences, University of Jordan, Amman, \\ Jordan
}

\begin{abstract}
The aim of this study was to explore secondary school teachers' degree of commitment to the code of ethical conduct from principals and assistant principals' perspectives. In order to collect all-important data, a questionnaire was developed on the basis of the literature. It was consisted of 60 items distributed on five domains related to teacher's ethical conduct towards him or herself, his or her students, colleagues and society in addition to the quality level of his or her performance. The population of the study comprised all principals and assistant principals $(\mathrm{n}=52)$ in secondary public schools $(\mathrm{n}=26)$ in Ain Albasha District, Amman. Out of the schools, 11 were male secondary schools and 15 were female secondary schools. Validated as well as questionnaires were administered to all members of the population. The results underlined that secondary public school teachers have a moderate level of ethical commitment. Basically, there was a significant relationship between teachers' degree of ethical commitment and the quality of their performance from the perspective of principals and assistant principals. Hence, school management should continually provide teachers with developmental courses to strength their professional ethical behavior due to its prominent role in improving their job behavior, which in turn helps in enriching the educational outcomes.
\end{abstract}

Keywords: Secondary school teachers, code of ethics, quality of performance

DOI: $10.7176 / \mathrm{JEP} / 11-31-05$

Publication date: November $30^{\text {th }} 2020$

\section{Introduction}

Ethics, as a crucial pillar for the development of civilizations and prosperity of nations, has become an essential part of life. One of the most vital roles of ethics is the organization of societies and individuals' life. On that account, the code of ethics has been applied to different sectors just as business and education sector is no exception. Altaweel (2001) highlighted the importance of ethics in the context of the educational process and indicated that ethics is a must for teachers in order to be able to align their students' positive values and attitudes towards the commitment to the ethical conduct. In such a case, teachers are proposed to get involved with a range of skills and expressly ethical dimensions. Alamayreh (2002) added that for a teacher to be able to fulfill his or her duties, he or she needs practical experiences and personal qualities as well as ethical system based on established ethical rules stemming from customs and traditions just like honesty, honesty, and cooperation.

That being the case, the interest in the development of a code of ethics for education was emerged to align the march of the education profession and to control its practitioner's behaviors which have a critical influence on the institutional efficiency and effectiveness (Yaghi, 2001). Ethical codes were regarded by organizations as a basic mean to guide the ethical conduct of individuals. In order to lay acceptable foundations that lend wings to the objectives of different professions, the interest in building ethical codes to govern these professions, especially the profession of education, was increased (Afifi, 2005) on the basis of the fact that teachers as a cornerstone of the educational system enact several significant parts such as ethical coaches, mentors and models who can transfer culture, develop their students values and integrate them into their societies (Alja'fari, 2010).

Numerous local and international studies have been conducted on teachers' commitment to the code of ethics. However, little research has examined the influence of teacher commitment on the quality of their performance. On the other hand, the Jordanian Ministry of Education has adopted the Code of Conduct and Ethics of the Public Service, which issued pursuant to the provisions of paragraph (a) of Article (67) of the Civil Service Law No. (82) of 2013. The focus of the code is on the principles of justice, professional integrity and impartiality. It was introduced as a mean to organize relationships between elements of the educational process (Alja'fari, 2010). Consequently, the aim of the current study was to investigate the degree of commitment to the code of ethical conduct among teachers of secondary public schools in Ain Albasha district and investigate the relationship between teacher commitment to the code of ethics and the quality of their performance from the perspective of principals and assistant principals. 


\section{Literature Review}

Numerous local and international studies have been carried out on teachers' commitment to the ethical code of conduct. One vein of the literature concerned with the extent to which teachers are committed to the code of ethical conduct in different countries. In an early study of Nazzal (2001), teachers were found to have a high degree of commitment to the ethics of teaching profession in Palestine. No statistically significant differences in teachers' commitment to the ethics were found from the perspective of principals and supervisors. Using a sample of school principals in Texas and gathering data on ethical values and the use of democratic principles. Huffman and Jacobson (2003) revealed a significant degree of ethical leadership style practice and positive ethical principles among principals. Abbas (2010) explored the degree of commitment to the ethics of administrative work among the heads departments in faculties of applied education in Kuwait from their perspectives and pointed out a high degree of commitment.

Concurrently, the aim of Al-Aziz's (2010) study was to identify the extent to which the teachers of the intermediate and secondary stages in the public schools in Riyadh have complied with the ethics of the teaching profession as seen by the female principals and female teachers. Her findings documented statistically significant differences between the opinions of female principals as well as teachers on the extent of teachers' commitment to the ethics of the teaching profession in terms of relationships with their colleagues, school management, students in addition to relationships with the local community and parents, respectively. Howard (2010) assessed middle schools teachers commitment to the code of ethics New South Australia through the instrumentality of a random sample consisted of 246 female teachers and made known that the degree of commitment among teachers was moderate to high. Besides, no significant differences in the level of commitment to the ethics were found among teachers in favor of their experience.

In the same vein, Popescu and Gunter study (2011) studied the ethics of the teaching profession among female primary and middle school teachers in different stages in Romanian schools. The results located a high level of commitment to ethics among female teachers in conjunction with significant differences in the level of ethical conduct in favor of middle stage female teachers. In a study by Kegler (2011), a sample comprised 78 male and female teachers was randomly selected for high schools in California in order to identify the commitment level to the code of ethics among teachers. The results recognized a high level of commitment to ethics with no significant differences that can be attributed to gender.

In Turkey, Ozbek (2012) surveyed 465 teachers and 398 principals in secondary schools in Ankara with an eye to determine the level of commitment of male and female teachers of physical education to the ethics of the teaching profession. The results showed a high level of commitment among teachers. The most important ethics were respect of others, integrity and honesty. The study pointed out significant differences in favor of females in the level of professional ethical commitment from the point of view of the teachers themselves. Yet, Mardhi (2015) carried out a study to identify the degree of commitment to the ethics of education amongst teachers of Islamic education for the intermediate stage of in Iraq from the perspective of school principals and educational supervisors. The results indicate a high level of commitment to ethics and there were no statistically significant differences in school principals and educational supervisors' estimations that attributed to age, qualification, years of experience and job.

In Jordan, Alhadid (2011) examined the commitment degree to the ethics of education profession among teachers of Islamic education for the secondary stage in Jordan from the viewpoint of principals. Based on data collected via a questionnaire from a sample included 148 male and female principals, the study pointed out a moderate degree of commitment to the ethics of teaching profession. Abu Siam (2016) also studies the degree of commitment to ethics among teachers in Amman using a sample encompassed 143 male and female principals. The overall degree of commitment to ethics was moderate. Particularly, teachers commitment towards parents was the highest dimensions, followed by commitment towards the education profession, their students, the local community and, finally, towards their colleagues. Given these results, it was observed that the relationship with teachers' commitment to the code of ethics and the quality of their performance was not estimated. Thus, the present was driven by twofold questions incidental to teachers' commitment to education code of ethics and to test its relationship with the quality of teachers' performance.

\section{Methodology}

\subsection{Population, sample and data collection}

The population of the study contained all male and female principals and assistant principals $(n=52)$ in secondary public schools $(\mathrm{n}=26)$ in Ain Albasha District, according to the statistics of the Ministry of Education for the year 2016-2017. Out of the schools, 11 were male schools and 15 were female schools. All members of the population were included in the study. Personal data of the participants were studied, as exhibited in Table 1, in terms of their educational qualification, specialization, and experience. 
Table 1. Distribution of participants according to demographic data

\begin{tabular}{clcc}
\hline Variable & \multicolumn{1}{c}{ Category } & Number & Percent \\
\hline Education level & Bachelor degree or less & 26 & 44.1 \\
& Master's degree & 13 & 22.0 \\
& Ph.D. & 17 & 28.8 \\
Area of specialization & Psychological and educational sciences & 17 & 28.8 \\
& Arts & 32 & 54.2 \\
& Applied sciences & 7 & 11.9 \\
Job experience & 5 years or less & 25 & 42.4 \\
& More than 5 years & 31 & 52.5 \\
\hline Total & & $\mathbf{5 2}$ & $\mathbf{1 0 0}$ \\
\hline
\end{tabular}

The findings reported that $44.1 \%(n=26)$ of the respondents have a bachelor's degree, $22 \%(n=13)$ of the participants have a master's degree while $28.8 \%(n=17)$ of the participants have attained a doctorate degree. Furthermore, the results in Table 1 demonstrated that 32 out of 52 participants have an area of specialization of Arts signify the highest percentage (54.2\%), followed by participants $(28.8 \%)$ who are specialized in psychological and educational sciences $(n=17)$, then the participants $(11.9 \%)$ who are specialized in applied sciences $(n=7)$.

\subsection{Measurements}

Teachers' degree of commitment to the code of ethical conduct was measured using 50 items distributed on five domains related to teacher's ethical conduct towards him or herself, his or her students, colleagues and society based on previous studies. Teachers' quality of performance was evaluated using 10 items

\subsection{Validity and reliability}

The validity of the questionnaire was tested by means of Pearson correlation coefficient used to estimate correlations between pairs of dimensions, as portrayed in Table 2, while reliability was assessed utilizing Cronbach's alpha method $(\alpha)$ as depicted in the same table. The results in Table 2 indicated that all dimensions of teacher's commitment to the code of ethics were positively correlated. Correlations were ranged from 0.48 to 0.86 $(\mathrm{P}<0.05)$. On the other hand, values of Cronbach's alpha ranged from 0.62 to 0.72 . All over, these results clarified that the questionnaire used in the current study to collect data from participants was valid and reliable.

Table 2. Pearson correlation matrix and Cronbach's alpha values

\begin{tabular}{llccccc}
\hline \multicolumn{1}{c}{ Variable } & $\mathbf{1}$ & $\mathbf{2}$ & $\mathbf{3}$ & $\mathbf{4}$ & $\mathbf{5}$ \\
\hline 1. Teacher's ethical conduct towards himself and work & $\mathbf{( 0 . 6 2 )}$ & & & & \\
2. Teacher's ethical conduct towards students & $0.53^{*}$ & $\mathbf{( 0 . 7 5 )}$ & & & \\
3. Teacher's ethical conduct towards colleagues & $0.48^{*}$ & 0.63 & $\mathbf{( 0 . 6 3 )}$ & \\
4. Teacher's ethical conduct towards society & $0.49^{*}$ & 0.48 & $0.73^{*}$ & $\mathbf{( 0 . 7 2 )}$ & \\
5. Teacher's quality of performance & $0.76^{*}$ & $0.86^{*}$ & $0.73^{*}$ & $0.72^{*}$ & $\mathbf{( 0 . 6 4 )}$ \\
\hline * Correlation coefficient is significant at 0.05; & & & & & \\
The diagonal line presents values of Cronbach's alpha; & & & & & \\
Overall scale alpha $=0.64$ & & & & & \\
\hline
\end{tabular}

\section{Results}

4.1 Teachers' commitment to the code of ethics

The first objective of this study was to explore teachers' commitment to the code of ethics from principals and assistant principals' perspective in terms of four dimensions: Teacher's ethical conduct towards himself and work, teacher's ethical conduct towards students, teacher's ethical conduct towards colleagues, and teacher's ethical conduct towards society. Table 3 shows that the overall degree of teachers' commitment to the code of ethics was moderate. Particularly, item no. 17 "Teachers are good example of students" was in the first rank $(\mathrm{M}=4.86, \mathrm{SD}$ $=1.49)$. Teachers were moderately rated modest and unpretentious as in item $8(\mathrm{M}=2.93, \mathrm{SD}=1.07)$. 
Table 3. Means and standard deviations of teachers' commitment towards him or herself and work

\begin{tabular}{clcccc}
\hline No. & \multicolumn{1}{c}{ Item } & Mean & SD & Rank & Degree \\
\hline 17 & Teachers are good example of students & 3.95 & 1.49 & 1 & High \\
10 & Teachers work enthusiastically and proactively & 3.87 & 1.12 & 2 & High \\
12 & Teachers can manage time in the classroom & 3.82 & 0.92 & 3 & High \\
6 & Teachers share new information acquired from colleagues & 3.77 & 1.31 & 4 & High \\
2 & Teachers care about their appearance without exaggeration & 3.59 & 1.18 & 5 & Moderate \\
14 & Teachers do well in dialogue and discussion & 3.57 & 1.07 & 6 & Moderate \\
11 & Teachers are committed to participate in school activities & 3.48 & 1.23 & 7 & Moderate \\
1 & Teachers do their work sincerely & 3.45 & 1.38 & 8 & Moderate \\
16 & Teachers coordinate their daily work with their colleagues & 3.43 & 1.48 & 9 & Moderate \\
15 & Teachers respect laws, regulations and instructions & 3.38 & 1.19 & 10 & Moderate \\
13 & Teachers are keen to discipline their behavior & 3.35 & 1.28 & 11 & Moderate \\
3 & Teachers refuse to accept gifts supplied for suspicion & 3.33 & 1.08 & 12 & Moderate \\
4 & Teachers are patient and wise & 3.29 & 1.22 & 12 & Moderate \\
5 & Teachers like reading in their area of specialization & 3.12 & 1.07 & 14 & Moderate \\
8 & Teachers are characterized by humility and & 3.11 & 1.46 & 15 & Moderate \\
\hline- & & 3.50 & 1.20 & - & Moderate \\
\hline
\end{tabular}

In relation to teachers' commitment towards his or her students, the results in Table 4 indicated a moderate degree of teachers' commitment $(\mathrm{M}=3.37$, $\mathrm{SD}=1.14)$. Teachers' knowledge of their students' academic needs was considered the highest important out of the items $(\mathrm{M}=4.93, \mathrm{SD}=1.35)$. However, teachers' treatment of students with respect and kindness was moderately important $(\mathrm{M}=3.00, \mathrm{SD}=1.19)$.

Table 4. Means and standard deviations of teachers' commitment towards his or her students

\begin{tabular}{clcccc}
\hline No. & \multicolumn{1}{c}{ Item } & Mean & SD & Rank & Degree \\
\hline 9 & Teachers know students' academic needs & 3.85 & 1.35 & 1 & High \\
8 & Teachers encourage students to be committed to good morals & 3.8 & 1.11 & 2 & High \\
7 & $\begin{array}{l}\text { Teachers direct students in the light of their intellectual tendencies } \\
\text { and talents }\end{array}$ & 3.78 & 1.21 & 3 & Moderate \\
1 & Teachers treat students with the spirit of parenting & 3.77 & 0.60 & 4 & Moderate \\
10 & Teachers allowed students to express their views in a positive & 3.59 & 1.17 & 5 & Moderate \\
4 & democratic atmosphere & 3.57 & 0.96 & 6 & Moderate \\
3 & Teachers direct and help students in problem solving & 3.48 & 0.81 & 7 & Moderate \\
5 & Teachers consider individual differences among students & 3.37 & 1.11 & 8 & Moderate \\
6 & Teachers avoid mentioning flaws of students in front of colleagues & 3.14 & 1.31 & 9 & Moderate \\
2 & Dealing with students with respect and kindness & 2.57 & 1.19 & 10 & Moderate \\
\hline- & & 3.49 & 1.14 & - & Moderate \\
\hline
\end{tabular}

As shown in Table 5, item 13 "Teachers positively solve problems with colleagues" had the highest mean value $(\mathrm{M}=4.13, \mathrm{SD}=1.14)$, while item 5 "Teachers avoid gossip among colleagues" was moderate in rank $(\mathrm{M}=$ $3.37, \mathrm{SD}=1.14)$.

Table 5. Means and standard deviations of teachers' commitment towards his or her colleagues

\begin{tabular}{|c|c|c|c|c|c|}
\hline No. & Item & Mean & SD & Rank & Degree \\
\hline 13 & Teachers positively solve problems with colleagues & 4.77 & 1.14 & $\overline{1}$ & High \\
\hline 12 & Teachers cooperate with colleagues in doing works & 3.73 & 0.81 & 2 & High \\
\hline 3 & Teachers respect colleagues & 3.66 & 1.17 & 3 & Moderate \\
\hline 4 & Teachers help colleagues when they need help & 3.64 & 1.27 & 4 & Moderate \\
\hline 14 & Teachers seeks to reform and solve the conflicts between teachers & 3.57 & 0.94 & 5 & Moderate \\
\hline 7 & Teachers trust colleagues & 3.51 & 1.08 & 6 & Moderate \\
\hline 1 & Teachers respect opinions of colleagues & 3.44 & 0.30 & 7 & Moderate \\
\hline 8 & Teachers deal with colleagues with kindheartedness & 3.37 & 1.35 & 8 & Moderate \\
\hline 6 & Teachers salutes colleagues with a smile & 3.35 & 1.08 & 9 & Moderate \\
\hline 2 & Teachers avoid offending colleagues & 3.3 & 0.91 & 10 & Moderate \\
\hline 9 & colleagues are keen to participate colleagues in various events & 3.22 & 1.46 & 11 & Moderate \\
\hline 10 & $\begin{array}{l}\text { Teachers relationship with colleagues is based on professional and } \\
\text { fraternal }\end{array}$ & 3.17 & 1.09 & 12 & Moderate \\
\hline 5 & Teachers avoid gossip among colleagues & 3.06 & 1.42 & 13 & Moderate \\
\hline- & Total & 3.52 & 1.24 & - & Moderate \\
\hline
\end{tabular}


The results in Table 6 underlined a high rank of item 12 "Teachers care about the environment and encourages its conservation" $(\mathrm{M}=4.30, \mathrm{SD}=1.12)$ and a moderate degree of item "Teachers avoid accepting suspicious gifts" $(\mathrm{M}=2.77, \mathrm{SD}=1.74)$.

Table 6. Means and standard deviations of teachers' commitment towards his or her society

\begin{tabular}{clccccc}
\hline No. & \multicolumn{1}{c}{ Item } & Mean & SD & Rank & Degree \\
\hline 12 & Teachers care about the environment and encourages its & 4.22 & 1.12 & 1 & High \\
& conservation & & 3.96 & 0.85 & 2 & High \\
6 & Teachers speak courteously and courteously with parents & 3.86 & 1.08 & 3 & High \\
2 & Teachers maintain the values and customs of society & 3.82 & 1.39 & 4 & High \\
10 & Teachers present ideas and developing the community & 3.78 & 0.88 & 5 & High \\
1 & Teachers develop national and humanitarian values among students & 3.48 & 1.04 & 6 & Moderate \\
5 & Teachers employ their relationships to serve students and society & 3.48 & Moderate \\
4 & Teachers participate in volunteer activities in community service & 3.38 & 1.24 & 7 & Moderate \\
11 & Teachers performs rights and duties with all honesty and accuracy & 3.3 & 0.85 & 8 & Moderate \\
7 & Teachers help educating community religiously and morally & 3.21 & 0.94 & 9 & Moded \\
3 & Teachers maintain friendly relations with the local community & 3.16 & 1.62 & 10 & Moderate \\
9 & Teachers encourages student contributions to community service & 2.86 & 1.54 & 11 & Moderate \\
8 & Teachers avoid accepting suspicious gifts & 2.77 & 1.74 & 12 & Moderate \\
\hline- & & 3.48 & 1.33 & - & Moderate \\
\hline
\end{tabular}

Results in Table 7 indicated that item 3 "Teachers assess their level of performance" was highly ranked first $(\mathrm{M}=4.39, \mathrm{SD}=1.28)$ while item "Teachers used collaborative working group approach" $(\mathrm{M}=2.44, \mathrm{SD}=0.94)$. Table 7. Means and standard deviations of teacher's quality of performance

\begin{tabular}{|c|c|c|c|c|c|}
\hline No. & Item & Mean & $\mathrm{SD}$ & Rank & Degree \\
\hline 3 & Teachers assess their level of performance & 4.39 & 1.28 & 1 & $\overline{\text { High }}$ \\
\hline 5 & Teachers establish applicable and measurable goals & 3.86 & 1.11 & 2 & High \\
\hline 7 & $\begin{array}{l}\text { Teachers had the skills that are associated with problem } \\
\text { identification and decision making }\end{array}$ & 3.77 & 1.36 & 3 & High \\
\hline 1 & Teachers used clear methods in teaching & 3.73 & 1.12 & 4 & High \\
\hline 8 & Teachers are committed to objectivity in their talks & 3.68 & 1.45 & 5 & High \\
\hline 9 & Teachers tends to use persuasion when speaking & 3.55 & 1.31 & 6 & Moderate \\
\hline 2 & $\begin{array}{l}\text { Teachers are always acquainted with what is new in the field of } \\
\text { specialization }\end{array}$ & 3.41 & 1.28 & 7 & Moderate \\
\hline 4 & $\begin{array}{l}\text { Teachers create a continuous need for education and improve its } \\
\text { quality }\end{array}$ & 3.14 & 1.42 & 8 & Moderate \\
\hline 6 & Teachers are convinced of work and insisted on success & 2.82 & 1.19 & 9 & Moderate \\
\hline 10 & Teachers used collaborative working group approach & 2.44 & 0.94 & 10 & Moderate \\
\hline- & Total & 3.47 & 1.11 & - & Moderate \\
\hline
\end{tabular}

4.2 Correlation between teachers' commitment to ethics and quality of performance

Pearson correlation matrix as illustrated in Table 8 showed statistically significant correlations between domains of teachers' degree of commitment to the code of ethics and the quality of their performance. Teacher's ethical conduct towards him or herself $(\mathrm{r}=0.76, \mathrm{P}<0.05)$, teacher's ethical conduct towards his or her students $(\mathrm{r}=0.86$, $\mathrm{P}<0.05)$, teacher's ethical conduct towards his or her colleagues $(\mathrm{r}=0.73, \mathrm{P}<0.05)$, and teacher's ethical conduct towards his or her society $(\mathrm{r}=0.72, \mathrm{P}<0.05)$ were positively correlated to teachers' quality of performance.

Table 8. Pearson correlation matrix

\begin{tabular}{llcccc}
\hline \multicolumn{1}{c}{ Variable } & $\mathbf{1}$ & $\mathbf{2}$ & $\mathbf{3}$ & $\mathbf{4}$ & $\mathbf{5}$ \\
\hline 1. & Teacher's ethical conduct towards him or herself & - & & & \\
2. Teacher's ethical conduct towards his or her students & $0.53^{*}$ & - & & & \\
3. Teacher's ethical conduct towards his or her colleagues & $0.48^{*}$ & 0.63 & - & & - \\
4. Teacher's ethical conduct towards his or her society & $0.49^{*}$ & 0.48 & $0.73^{*}$ & - & - \\
5. Teacher's quality of performance & $0.76^{*}$ & $0.86^{*}$ & $0.73^{*}$ & $0.72^{*}$ & - \\
\hline * Correlation coefficient is significant at 0.05 & & & &
\end{tabular}

\section{Discussion and conclusion}

The aim of this study was twofold. First, it tries to identify the degree of teachers' degree of commitment to the code of ethics. Second, to explore the relationship between teachers' commitment to ethics and their quality level of performance. Teachers' degree of commitment to the code of ethics was evaluated in terms of their ethical 
conduct towards themselves, their students, their colleagues and towards their society. The results pointed out that the degree of teachers' commitment to the code of ethics was generally moderate from the perspectives of principals and assistant principals. It was revealed that all dimensions of teachers' commitment to the code of ethics were moderate. The results of the present study were in agreement with Nazzal (2001) and Mardhi (2015). Perhaps the reason for this is the Ministry of Education's approval of the Code of Ethics and Public Service Ethics. In accordance with the provisions of paragraph (a) of Article 67 of the Civil Service Law No. 82 of 2013.

According to the results, teachers' ethical conduct towards their colleagues was ranked first $(\mathrm{M}=3.52)$. The first item in this domain indicated that the teacher is positive in solving problems with colleagues. This result can be explained by the role of schools managers in providing a positive atmosphere between teachers and work to solve problems together. The last item in the domain indicates that the teacher avoids gossip, and the reason for this, of course, is the style of democratic leadership prevailing in the school, and the religious and moral education of the teacher, which regarded these acts as unacceptable.

Teacher's ethical conduct towards her or himself and his or her work was moderate $(\mathrm{M}=3.50)$. The first paragraph in this area is the item that shows that the teacher is a good role model for students, and this is due to social reasons and the teacher's desire to obtain a good reputation, the result also reflects the religious education received by the teacher. The last paragraph in the field has shown that the teacher is modest, and of course an inherent characteristic of the person who is a good example. Then, teacher's ethical conduct towards his or her students was ranked third $(\mathrm{M}=3.49)$. The reason behind this result is the age group of students in high school, their treatment is based on respect and at the same time requires a bit of firmness, noting that the most important features of this stage the student's tendency to independence and express opinion and self-assertion.

Finally, the results highlighted that teacher's ethical conduct towards society was moderate $(\mathrm{M}=3.48)$. The results indicated that the paragraph that expresses teacher's interest in the environment and the promotion of its conservation has come in first place. This can be justified by the initiatives of the Ministry of Education and the Queen Rania Academy of Excellence that promote the achievement of a green school environment. The item that shows that the teacher refuses to accept the suspicious gifts came in the last rank, and perhaps the reason is the religious education of the teacher. On the other hand, the results showed a positive correlative relationship from the point of view of the study sample members towards the moral commitment of the teachers in secondary government schools and the quality of their performance. This result is logically reasonable in that increasing the degree of ethical commitment leads to increased quality of performance.

\section{Limitations, recommendations and future research directions}

One of the most important determinants of the study is that it was a cross-sectional study conducted in the general secondary schools in Ain al-Basha, which limits the possibility of generalizing its results to the rest of the schools in different regions. In the light of its findings, the study recommends that courses on the ethics of the teaching profession should be offered to undergraduate students and not only to higher education students, in addition to holding training courses for teachers on the ethics of education, and to promote the moral behaviors of teachers. Future studies should be conducted on the extent of teachers' commitment in the different directorates of education and their relationship to other variables in order to increase understanding of the subject

\section{References}

Abbas, A. (2010). The degree of commitment of scientific departments heads to the ethics of administrative work and its relationship to the level of morale of faculty members in the faculties of the General Authority for Applied and Educational Education from members perspectives. Kuwait, Unpublished Master Thesis, Middle East University, Jordan.

Abdul Aziz, M. (2010). The extent of the commitment of the intermediate and secondary teachers in the public schools in Riyadh city to the ethics of the profession of education in light of the variables, King Saud University Journal of Educational Sciences and Studies, 22 (3) 467-542.

Abu Siam, A. (2016). The reality of the professional moral commitment of teachers in the schools of Amman and its relationship to their behavior from school principals' perspectives, Unpublished Master thesis, University of Jordan: Jordan.

Afifi, S. (2005). Teacher's professional ethics. Cairo: League of Arab States, Arab Organization for Administrative Development.

Alamayreh, A. (2002). Principles of school management, Faculty of Educational Sciences, Amman: Dar Al Masirah for Publishing and Distribution.

Alhadid, N. (2011). Degree of commitment of teachers of Islamic education in the secondary stage to the ethics of the profession from schools principals in Aden, unpublished Master thesis, Faculty of Educational and Technical Sciences, Amman Arab University, Amman: Jordan.

Alja'fari, M. (2010). Human and Education, Amman: Dar Al Yazuri.

Altaweel, H. (2001). Educational administration and organizational behavior, Amman: Wael Publishing and 
Publishing House, 3rd Ed.

Howard, K. (2010). Principles and ethics for elementary and junior high school teacher. Liberty University.

Huffman, J. and Jacobson, A. (2003). Perceptions of professional learning communities. International Journal of Leadership in Education, 6(3), 239-250.

Kelger, D. (2011). Gender Differences in Perceptions of Ethics Among Teacher Education Students at San Diego State University, Unpublished PhD Thesis, Alliant International University, San Diego.

Mardhi, A. (2015). The degree of commitment of the teachers of Islamic education to the middle stage in the ethics of education in Anbar province from the point of view of school principals and educational supervisors, Unpublished Master thesis in the curriculum of Islamic education and methods of teaching, Al-Bayt University: Jordan.

Nazzal, M. (2001). The ethics of the profession of education in the light of Islamic thought and the extent of commitment of teachers from the perspectives of principals and supervisors in Palestine, Unpublished Master thesis, Al-Quds University: Palestine.

Ozbek, O. (2012). The levels of compliance of physical education teacher with professional ethic odes, Ankara University, Ankara, Turkey.

Popescu, A. and Gunter, H. (2011). Romanian women head teachers and the ethics at care. School leadership \& management, (3), 261-279.

Yaghi, M. (2001). Ethics in management, Alyakadah Library for Publishing and Distribution: Amman. 